\title{
Learning from Lisbon Or, how postmodernism conquered Portugal
}

\author{
Reuben Connolly Ross \\ Universidade Católica Portuguesa - hello@reubenross.net
}

\begin{abstract}
The Amoreiras shopping centre in Lisbon is an icon of Portuguese postmodernism. When it first opened in 1985, its kitsch design stood out conspicuously amidst a landscape of smart Pombaline shopping streets, social housing tower blocks and tourist-friendly houses clad in "traditional" azulejo tiles. But it also reflected a pivotal moment in Portuguese history and still stands today as a reminder of the consumerist aspirations of post-revolutionary Portu-

dominate life in many Western nations and the stark contradictions of global capitalism. Departing from an initial discussion of Amoreiras, this short essay critically explores recent transformations to Lisbon's urban and architectural landscape and traces their political and economic origins. In so doing, it suggests ways in which postmodernism might be considered a relevant concept for describing contemporary Portuguese society.
\end{abstract} gal, the neoliberal policies that have come to

Keywords: postmodernism, architecture, urban history, Lisbon, Portugal.

\section{Lições de Lisboa Ou como o pós-modernismo conquistou Portugal}

\section{Resumo}

O centro comercial Amoreiras, em Lisboa, é um ícone do pós-modernismo português. Quando abriu pela primeira vez em 1985, o seu design kitsch destacou-se de forma conspícua no meio de uma paisagem de elegantes ruas comerciais pombalinas, edifícios de habitação social e casas turísticas revestidas de azulejos "tradicionais". Mas também refletiu um momento crucial na história portuguesa e ainda permanece hoje como uma lembrança das aspirações consumistas do Portugal pós-revolucionário, das políticas neoliberais que passaram a dominar a vida em muitas nações ocidentais e das contradições gritantes do capitalismo global. Partindo de uma discussão inicial sobre as Amoreiras, este pequeno ensaio explora criticamente as transformações recentes na paisagem urbana e arquitetónica de Lisboa e traça as suas origens políticas e económicas. Ao fazê-lo, sugere formas através das quais o pós-modernismo pode ser considerado um conceito relevante para descrever a sociedade portuguesa contemporânea.

Palavras-chave: pós-modernismo, arquitetura, história urbana, Lisboa, Portugal. 
The Amoreiras shopping centre watches over Lisbon, its bright colours and reflective surfaces glistening in Portugal's perpetual sunlight. When it first opened its doors in 1985, its kitsch design stood out conspicuously amidst a landscape of smart Pombaline shopping streets, social housing tower blocks and tourist-friendly houses clad in "traditional" azulejo tiles. Its glass towers rose high into the sky, its monumental scale dominating Lisbon's urban landscape. Inside, its 45,000 square metres of shady and disorienting spaces enveloped the unsuspecting visitor in an intoxicating state of frenzied consumerism; on the ground level, it even contained its own small church, lending ironic new meaning to George Ritzer's famous description of shopping malls as "cathedrals of consumption" (Amoreiras Shopping Center, n.d.; Ritzer, 2010). And so, when over 10,000 visitors (Amoreiras Shopping Center, n.d.) passed through the doors on its opening day, it was no surprise that Amoreiras "captured the public's imagination in a spectacular way" (Broadbent, 1990, p. 9) - and quickly became an icon of Portuguese postmodernism.

The centre was designed by Tomás Taveira, a controversial architect who first gained notoriety in the 1980s for having helped introduce postmodernist architecture to Portugal. Having initially studied in Lisbon during the 1960s, he later completed his postgraduate studies in the United States, returning with a sense that "architecture must be, beyond everything, art: provoking emotion, the controversial, the contradictory" (Taveira, 2002, p. 18). So, if Charles Jencks once defined postmodern architecture by its "radical eclecticism," by its tendency towards "the vernacular, towards tradition and the commercial slang of the street," it was no surprise that it could later be seen in Amoreiras (Jencks, 1978, p. 6). In fact, one might even detect similarities to other postmodern landmarks: the decorative flourishes of Michael Graves' Portland Building, perhaps, or the reflective surfaces of John Portman's Westin Bonaventure Hotel. But Amoreiras, insisted Taveira, was different. "We haven't sought a simple image of progress," he says. "We didn't design the buildings so that they were an affirmation of technology." Instead, he claims, "they are placed in the position to affirm a possible architectural culture for our country and for Lisbon in particular" (Cardim, 2013, p. 153). To understand that desire, its origins must be traced back several decades. 


\section{Figure 1}

The Amoreiras shopping centre, 1985 (Arquivo Municipal de Lisboa)

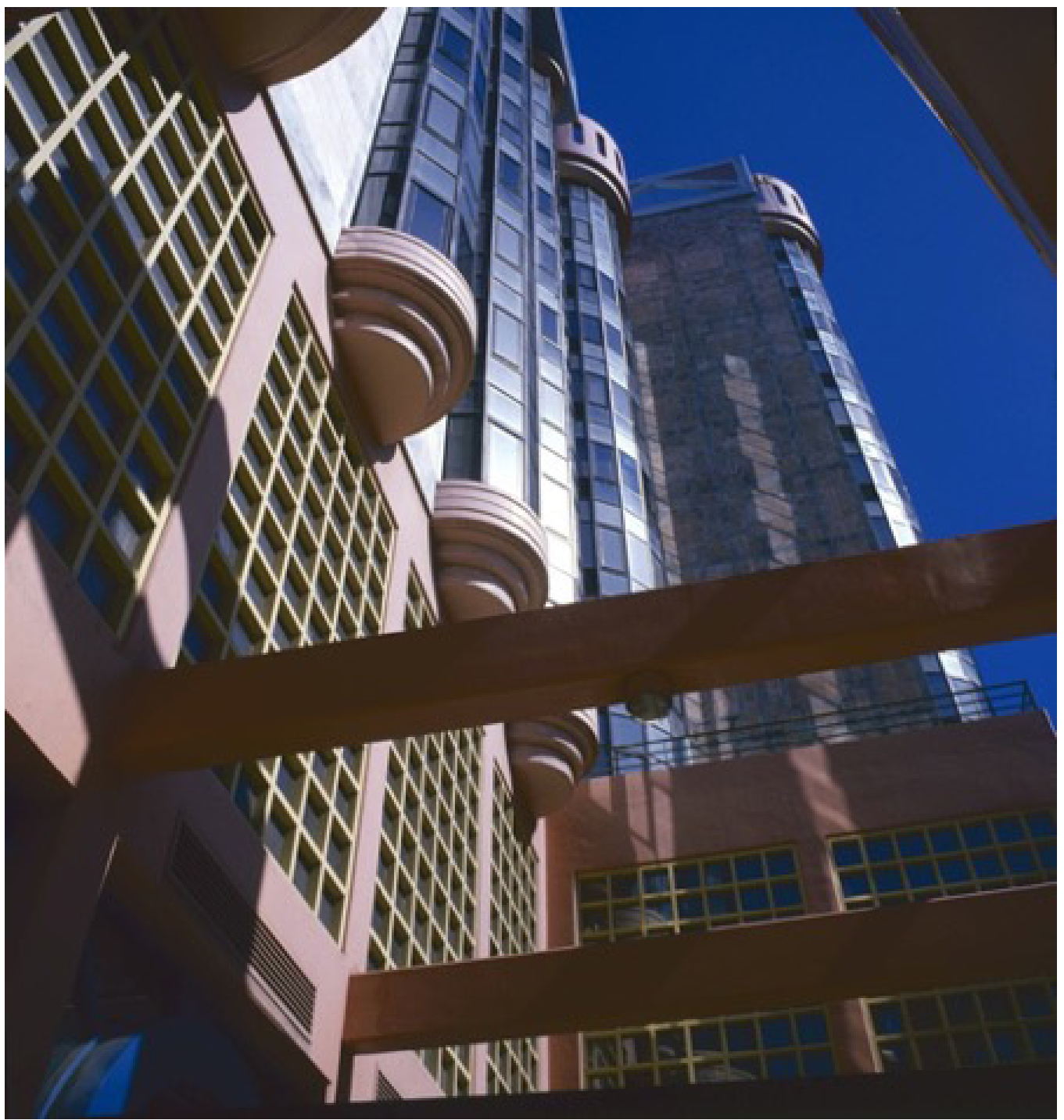

Under the Estado Novo, Portugal's forty-year long dictatorial regime, most major industrial development and economic growth had been severely repressed. Led by António de Oliveira Salazar, the country's economy remained largely agricultural, most of the population lived in rural areas and private enterprise was controlled 


\section{Learning from Lisbon}

Or, how postmodernism conquered Portugal

by just forty prominent families. The regime especially opposed industrial growth whenever it was seen to encourage "modernising" trends such as consumerism and secularism; Portugal was a devout Catholic nation, socially conservative and largely peripheral to the European and world economy. Architecturally, this conservatism manifested in two distinct ways: on one hand, the regime often rejected modernist trends seen elsewhere in Europe and, on the other, it enforced the development of a nationalist architecture based on the "eternal spirit" of the Portuguese people. As such, most major architectural projects during the Estado Novo generally stressed a continuity with Portugal's past, favouring neo-classical and "traditionalist" styles, while reluctantly embracing only an attenuated modernist aesthetic. Yet, this decidedly parochial approach was not without its detractors; at one point, Salazar lamented that young Portuguese architects were not producing buildings that "[fit] our race and our climate," instead "subserviently following foreign models" (Carvalho, 2018, p. 147).

By the final years of the Estado Novo, however, things were beginning to change (Baklanoff, 1992). In 1968, when a stroke left Salazar bed ridden, his replacement by Marcelo Caetano coincided with a period of great economic transformation and political reform. A surge in foreign investment helped fuel the expansion and diversification of the country's nascent manufacturing industry. A subsequent rise in wages opened up new channels of social mobility, boosting demand for consumer goods. And a wave of migration to Portugal's major cities greatly accelerated processes of urbanisation. The Portuguese economy was opening up, but even bigger changes would soon take place to the very nature of global capitalism itself. In the early 1970s, following years of sustained post-war growth, the world economy was plunged into recession when the Bretton Woods system collapsed, followed by the so-called oil crisis of 1973. As David Harvey notes, this led to a "troubled period of economic restructuring and social and political readjustment," which would ultimately usher in an "entirely new regime of accumulation" (1992, p. 145). And so, on the eve of its peaceful "Carnation Revolution," Portugal stood poised to embrace a world of great economic uncertainty.

It was during this time that the first small shopping centres emerged in Lisbon and Porto. When Apolo 70 opened to great fanfare in 1971, it comprised a modest 41 shops spread across two floors; its sleek, space-age interiors designed by renowned artist Paulo Guilherme d'Eça Leal. A new Portuguese consumer culture was surely emerging, though it was not until the late-1980s that larger, American-style shopping malls were constructed. Following Portugal's accession to the European Economic 
Community (EEC), a precursor to the European Union (EU), a new wave of foreign investment and market liberalisation sparked a veritable bonanza of consumerism: the CascaiShopping complex was opened in 1991, strategically located in Lisbon's wealthy western suburbs, followed by a succession of shopping centre openings up and down the country. By 1997, this culminated with the completion of Colombo, one of the largest shopping complexes in Europe, its postmodern arcades and faux town squares incongruously themed around Portugal's so-called "age of discoveries." It offered over 400 shops, dozens of restaurants, a health club with two swimming pools, a 10-screen multiplex cinema and, of course, a church.

\section{Figure 2}

The Apolo 70 shopping centre, 1977 (Arquivo Municipal de Lisboa)

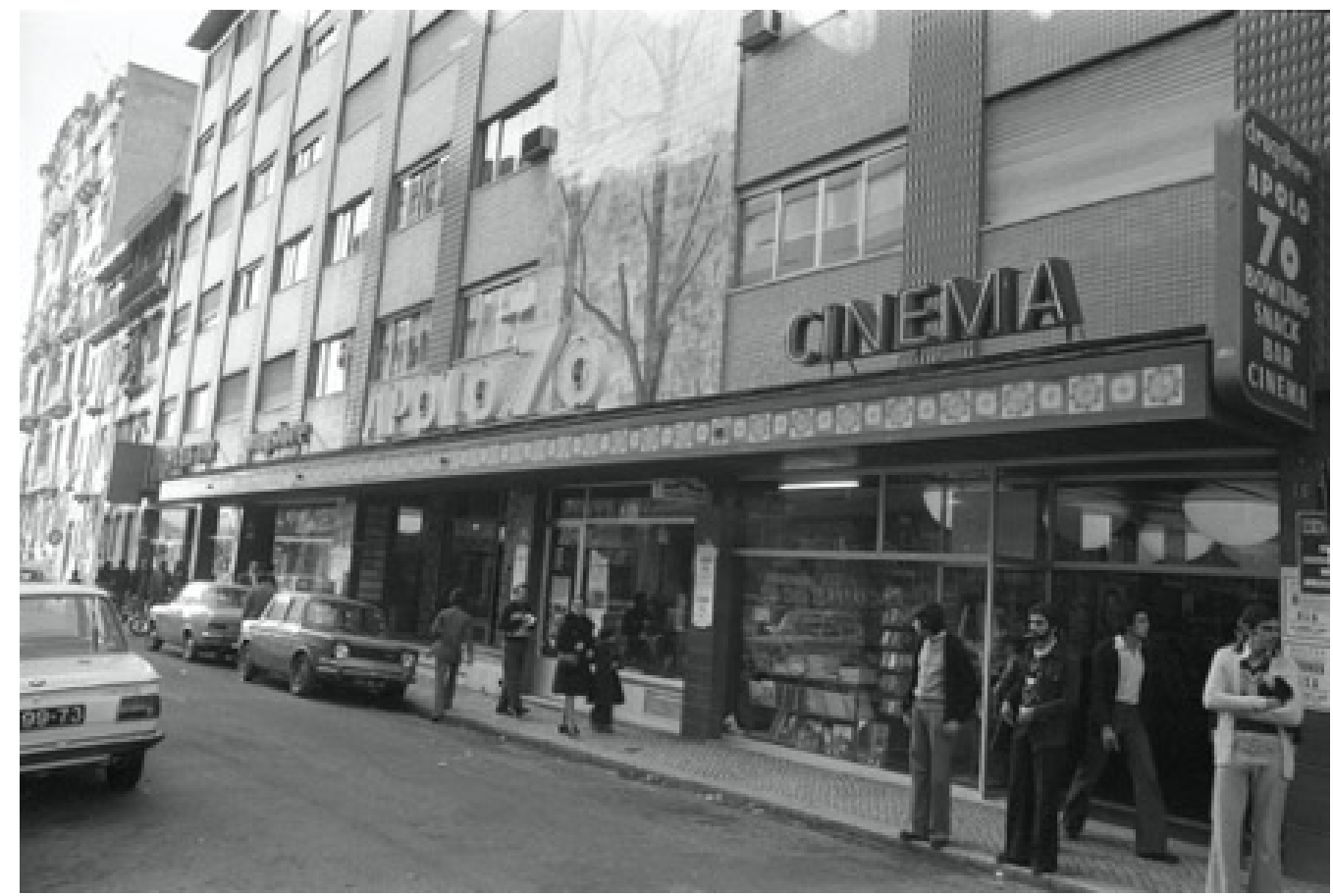

Meanwhile, with the opening of each successive shopping centre, Lisbon's urban landscape was becoming increasingly fragmented. For centuries, the city's baixa district, with its grid-patterned streets and smart Pombaline architecture, had served as its main commercial hub. But a mixture of neoliberal reforms, combined with 
the increasing prominence of the private property market, as well as a lack of intermunicipal cooperation, resulted in a process of sprawling suburbanisation and the emergence of multiple, geographically dispersed commercial centres (Lund Hansen, 2003; Tulumello, 2015). Between 1991 and 2011, Lisbon's city centre lost over a third of its population, while the broader metropolitan region gained over 300,000 new residents (Lestegás, 2019). Arguably, this process of urban restructuring (culminating in major urbanisation projects such as EXPO '98 and the POLIS Programme) marked the emergence of what Manuel Castells ominously calls "the Wild City," later reformulated by Edward Soja as the "post-metropolis," a bewildering new reality in which "the contemporary city seems to be increasingly unmoored from its spatial specificity, from the city as a fixed point of collective reference, memory and identity" (Castells, 1977, p. 427; Soja, 2000, p. 150). By the turn of the new millennium, shopping malls such as Amoreiras had largely overtaken "traditional" shopping streets as Lisbon's principal commercial spaces.

\section{Figure 3}

The Colombo shopping centre, 2020 (Arquivo Municipal de Lisboa)

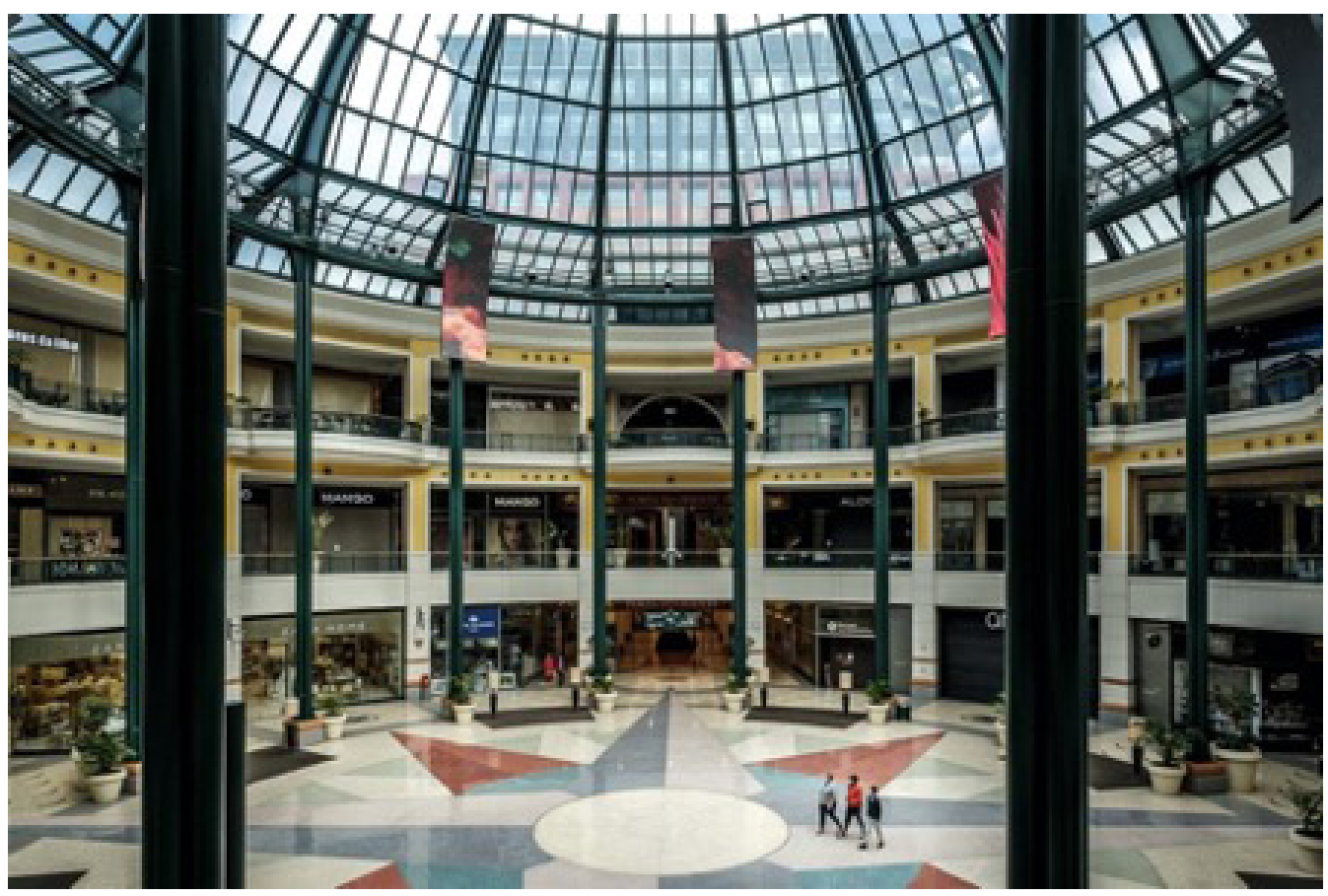


The financial crisis of 2007-8 only deepened the contradictions of Portugal's "postmodern condition" (Lyotard, 1984). When the world economy once again entered recession, the effects on Portuguese society were devastating, including massive job losses and increased unemployment, a rise in emigration and the significant worsening of social inequalities. By 2011, the country was compelled to negotiate an unprecedented "economic adjustment programme" with the EU and IMF, including a financial bailout package of some 78 billion euros (European Union, 2014). The right-wing PSD/CDS-PP government at the time, led by Pedro Passos Coelho, swiftly introduced deep structural reforms, allegedly designed to boost potential growth, create jobs, and improve economic competitiveness. Instead, a rapid liberalization programme resulted in the large-scale deregulation of a number of key economic sectors, the introduction of policies specifically designed to attract further foreign investment and, crucially, the affirmation of tourism as an integral part of Portugal's post-crisis economy.

Today, the tourism industry exceeds $16 \%$ of Portugal's gross domestic product. Each year, it contributes over 30 billion euros to the country's economy and employs nearly a million of its citizens (World Travel \& Tourism Council, 2018). In Lisbon in particular, it has fuelled a relentless process of tourism-driven gentrification, as many inner-city residents are priced out of their homes and the short-term rental market gains increasing prominence (Lestegás, 2019; Cocola-Gant \& Gago, 2019). The result has been "a tacit change in land use from residential to tourist uses that residents experience as a process of social injustice" (Cocola-Gant \& Gago, 2019, p. 3). Meanwhile, the cultural impact has been equally serious; as tourists travel to their holiday destinations, notes John Urry, they "gaze upon or view a set of different scenes, of landscapes or townscapes," which are hastily "objectified or captured through photographs, postcards, films, models and so on" (2002, pp. 1, 3). Thus, local cultures are unceremoniously transformed into material things that can be endlessly reproduced, recaptured and redistributed around the world; a "society of the spectacle," as Guy Debord famously writes, in which "everything that was directly lived has receded into a representation" (2005, p. 7).

Back at Amoreiras, its bright colours and reflective surfaces remain an enduring symbol of how the country has changed over the past few decades. Today, the shopping centre welcomes, on average, over 12 million visitors each year; according to promotional material, it has now become "an obligatory stop for residents and tourists" alike (Amoreiras Shopping Center, n.d.). And yet, beyond its significance 


\section{Learning from Lisbon}

Or, how postmodernism conquered Portugal

as a mere shopping destination, Amoreiras also stands as an uneasy reminder of the consumerist aspirations of post-revolutionary Portugal, the neoliberal policies that have come to dominate life in many Western nations and the stark contradictions of global capitalism. Its towers reflect the economic changes and political turmoil that have helped produce radically new urban forms; its imposing size epitomises the devastating effects of uneven spatial development; its kitsch designs embody a kaleidoscopic vision of an uncertain future. Indeed, perhaps Taveira's "radical eclecticism," so boldly expressed in the Amoreiras shopping centre, really did mark the emergence of a certain postmodern sensibility in Portuguese culture. But, above all, Amoreiras compels us to consider what modern-day Portugal has become, where it might be going and - most urgently of all - what lessons can be learnt.

\section{REFERENCES}

Amoreiras Shopping Center. (n.d.). About. Retrieved October 1, 2020, from https:// amoreiras.com/en/about

Baklanoff, E. N. (1992). The Political Economy of Portugal's Later "Estado Novo": A Critique of the Stagnation Thesis. Luso-Brazilian Review, 29 (1), 1-17.

Broadbent, G. (1990). Introduction. In Tomás Taveira. Academy Press/St. Martin’s Press.

Cardim, J. (2013). The role of shopping malls in shaping the Lisbon Metropolitan Area: The Amoreiras Shopping Center case study. Revista Lusófona de Arquitectura e Educação, 8-9, 145-169.

Carvalho, R. A. (2018). Ideology and architecture in the Portuguese "Estado Novo": Cultural innovation within a para-fascist state (1932-1945). Fascism, 7, 141174. https://doi.org/10.1163/22116257-00702002

Castells, M. (1977). The urban question: a Marxist approach. Edward Arnold.

Cocola-Gant, A \& Gago, A. (2019). Airbnb, buy-to-let investment and tourism-driven displacement: A case study in Lisbon. EPA: Economy and Space, 0(0), 1-18.

Debord, G. (2005). Society of the spectacle. Rebel Press. 
European Union. (2014). The economic adjustment programme for Portugal 2011-2014. https://ec.europa.eu/economy_finance/publications/occasional_paper/2014/ pdf/ocp202_en.pdf

Harvey, D. (1992). The condition of postmodernity: an enquiry into the origins of cultural change. Blackwell.

Jencks, C. (1978). The language of post-modern architecture (2nd ed.). Academy Press.

Lestegás, I. (2019). Lisbon After the Crisis: From Credit-fuelled Suburbanization to Tourist-driven Gentrification. International Journal of Urban and Regional Research, 43(4), 705-723. https://doi.org/10.1111/1468-2427.12826

Lund Hansen, A. (2003). Rescaling of the commercial property market and changing urban governance in Lisbon. Géocarrefour, 78(4), 301-312. https://doi. org/10.4000/geocarrefour.362

Lyotard, J.-F. (1984). The postmodern condition: a report on knowledge. University of Minnesota Press.

Ritzer, G. (2010). Enchanting a disenchanted world: Continuity and change in the cathedrals of consumption. Pine Forge Press.

Soja, E. (2000). Postmetropolis: critical studies of cities and regions. Blackwell.

Taveira, T. (2002). Interview: Tomás Taveira talks to Maggie Toy. In Tomás Taveira. Artmedia Press.

Tulumello, S. (2015). Reconsidering neoliberal urban planning in times of crisis: urban regeneration policy in a "dense" space in Lisbon. Urban Geography, 37(1), 117-140. https://doi.org/10.1080/02723638.2015.1056605

Urry, J. (2002). The tourist gaze (2nd ed.). Sage.

World Travel \& Tourism Council. (2018). Travel and tourism economic impact 2018 Portugal. https://www.sgeconomia.gov.pt/ficheiros-externos-sg/wttc_ portugal2018-pdf.aspx 